\title{
Adult onset Still's disease and viral infections
}

\author{
JACQUES M G W WOUTERS, ${ }^{1}$ JOHAN VAN DER VEEN ${ }^{2}$ \\ LEVINUS B A VAN DE PUTTE, ${ }^{\prime}$ AND DIRK-JAN R A M DE ROOIJ
}

From the Departments of ${ }^{1}$ Rheumatology and ${ }^{2}$ Microbiology, University Hospital Nijmegen, Nijmegen, The्ष
Netherlands; and ${ }^{3}$ St Maartens Clinic, Nijmegen, The Netherlands

SUMMARY Several micro-organisms, especially viruses, have been associated with juvenile and adult onset Still's disease. In the present study a search for probable triggering viral infections in five consecutive patients with early, active adult onset Still's disease has been made. In ones patient echovirus 7 was identified as a probable triggering agent. Evidence of infection with thiso virus was acquired by virus cultures and serological tests. In two patients the illness was probably initiated by a rubella reinfection. Both had initially high stable monospecific IgG antibody titres but no IgM antibodies to this virus. In the remaining two cases no particular triggering vira infection could be designated. Evidence of a viral infection was thus found in three of these five $\overrightarrow{e s}$ patients. Adult onset Still's disease may represent a reaction pattern to certain infections.

Key words: echovirus, rubella, cultures, serology.

Juvenile and adult onset Still's disease are related clinical entities characterised by high spiking fever, an evanescent maculopapular rash, and arthritis. ${ }^{12}$ Other features frequently found in both conditions include lymphadenopathy, splenomegaly, pericarditis, pleuritis, neutrophil leucocytosis, and hepatic abnormalities. Although the cause of these diseases is unknown, several recent reports have associated their development with a variety of microorganisms, especially viruses. ${ }^{3-12}$

The present study reports on virological studies performed in five patients with adult onset Still's disease in an early phase of the disease.

\section{Patients and methods}

PATIENTS

During 1983 five patients with early, active adult onset Still's disease were seen at two hospitals in the city of Nijmegen, The Netherlands (CanisiusWilhelmina Hospital, University Hospital St Radboud). All presented with fever of unknown origin and fulfilled the criteria of Medsger and Christy. ${ }^{13}$

\section{METHODS}

As soon as it was suspected that a patient was

Accepted for publication 26 November 1987.

Correspondence to Professor Levinus B A van de Putte, Department of Rheumatology, University Hospital Nijmegen, Geert Grooteplein Zuid 8, 6525 GA Nijmegen, The Netherlands. suffering from adult onset Still's disease virologic studies were started.

\section{Serology}

IgG antibody titres to adenovirus, respiratory synő cytial virus, mumps, cytomegalovirus, measles $\stackrel{\square}{\varnothing}$ herpes simplex, varicella, Coxsackie virus $B 1,2,3 \overrightarrow{\vec{F}}$ 4, 5, and 6, Coxiella burneti, psittacosis, ancB Mycoplasma pneumoniae were measured by complement fixation tests, IgG antibody titres tỡ? rubella and parainfluenza virus 1,2 , and 3 by haemagglutination inhibition tests, IgG antibody? titres to Epstein-Barr virus by immunofluorescence tests, and hepatitis B surface antigen ( $\mathrm{HBsAg}$ ) anक IgG antibodies to $\mathrm{HBsAg}$ by means of an enzyme linked immunosorbent assay (ELISA). IgG antibody titres to corona virus and influenza virus $A, B$, and $C$ were measured by complement fixation and haemagglutination inhibition tests. IgM antibodies: to mumps, rubella, and parainfluenza virus 1,2 , and 3 were assayed by haemadsorption immunosorbent tests and IgM antibodies to Epstein-Barr virus by immunofluorescence tests.

\section{Virus cultures}

All throat swabs and stool specimens were inocu lated in Flow 2002 (human lung fibroblasts), $\mathrm{HEp}_{2}-$ (human larynx carcinoma), and primary rhesus monkey kidney cells. Attempts to isolate rubella virus were made only if the IgG antibody titres to 
this virus were $1 / 512$ or less. In these cases throat swabs and urine specimens were inoculated in Vero cells.

\section{Results}

Table 1 shows the main clinical and laboratory findings in the five patients with adult onset Still's disease. Table 2 shows the number of days after onset of the disease at which the first and second blood specimens, the throat swab, and the stool specimen were collected in each case. When the first blood specimens for antibody determinations were drawn all patients had normal gammaglobulin concentrations at serum protein electropheresis. None

Table 1 Clinical and laboratory findings in the five patients with adult onset Still's disease

\begin{tabular}{|c|c|c|c|c|c|}
\hline & \multicolumn{5}{|c|}{ Patient No } \\
\hline & 1 & 2 & 3 & 4 & 5 \\
\hline Sex & $\mathbf{M}$ & $\mathbf{F}$ & $\mathbf{F}$ & $\mathbf{F}$ & $\mathbf{M}$ \\
\hline Age at onset (years) & 21 & 39 & 36 & 18 & 19 \\
\hline Sore throat & + & - & + & + & + \\
\hline Myalgias & + & + & + & + & + \\
\hline Fever, $39^{\circ} \mathrm{C}$ & + & + & + & + & + \\
\hline Typical rash & + & + & + & + & - \\
\hline Arthritis & + & + & + & + & + \\
\hline Lymphadenopathy & + & - & + & - & + \\
\hline Splenomegaly & + & - & + & - & + \\
\hline Pleuritis & + & - & - & - & - \\
\hline Pericarditis & + & - & - & - & + \\
\hline $\begin{array}{l}\text { Maximum ESR* }(\mathrm{mm} / \mathrm{h}) \\
\text { Lowest haemoglobin }\end{array}$ & 103 & 125 & 128 & 96 & 52 \\
\hline concentration $(\mathrm{g} / \mathrm{l})$ & $98 \cdot 2$ & $86 \cdot 9$ & $109 \cdot 5$ & $86 \cdot 9$ & $101 \cdot 4$ \\
\hline Highest leucocyte & & & & & \\
\hline count $\times 10^{-9} / 1$ & $25 \cdot 7$ & $12 \cdot 6$ & $16 \cdot 8$ & $18 \cdot 9$ & $14 \cdot 4$ \\
\hline Hepatic abnormalities & + & + & + & & \\
\hline attack (months) & 9 & 3 & $3 \cdot 5$ & $2 \cdot 5$ & $1 \cdot 5$ \\
\hline Follow up (months) & 24 & 23 & 23 & 23 & 18 \\
\hline \multicolumn{6}{|c|}{$\begin{array}{l}{ }^{*} \mathrm{ESR}=\text { erythrocyte sedimentation rate. } \\
+=\text { present; }-=\text { absent }\end{array}$} \\
\hline \multicolumn{6}{|c|}{$\begin{array}{l}\text { Table } 2 \text { Number of days after onset of the disease at } \\
\text { which the first and second blood specimens, the throat } \\
\text { swab, and the stool specimen were collected in each case }\end{array}$} \\
\hline & \multicolumn{5}{|c|}{ Patient No } \\
\hline & 1 & 2 & 3 & 4 & 5 \\
\hline \multicolumn{6}{|l|}{ Blood specimen } \\
\hline first & 14 & 16 & 17 & 26 & 15 \\
\hline second & 43 & 30 & 39 & 54 & 46 \\
\hline Throat swab & 16 & 39 & 34 & 54 & 46 \\
\hline Stool specimen & 16 & 30 & 39 & 54 & 47 \\
\hline
\end{tabular}

of the sera contained HBsAg or antibodies to HBsAg. Only two of the virus cultures yielded a positive result (Table 3 ). In patient No 3 echovirus 7 was isolated from a throat swab obtained at day 34 after onset of the illness and from a stool specimen obtained at day 39 . Neutralising antibody titres to this virus showed a fourfold increase. During 1983 only one other case of echovirus 7 infection was identified at our virological laboratory.

In patients 1 and 5, high IgG antibody titres to rubella were noted two weeks after onset of the disease (patient 1: $1 / 2048$, patient 5: 1/4096). Similar high IgG antibody titres to rubella were not found in a control group of 48 healthy Dutch blood donor volunteers. Fig. 1 shows the course of the rubella haemagglutination inhibition titres in patients 1 and 5 throughout the study period. During 1983 no epidemic of rubella was observed in The Netherlands.

In the serum of patient 4 high stable IgG antibody titres were detected to no less than five viruses:

Table 3 Main virological data for the five patients with adult onset Still's disease.

\begin{tabular}{llll}
\hline Patient & Virus cultures & IgM antibodies & IgG antibody titres \\
\hline 1 & - & - & Rubella (1/2048) \\
2 & - & - & - \\
3 & Echovirus 7 & - & Echovirus 7 (1/8, 1/32) \\
4 & - & Parainfluenza & Parainfluenza 1 and 3 \\
& & 1 and 3 & Rubella (1/2048) \\
& & & Measles (1/256) \\
& & & Adenovirus (1/128) \\
5 & - & - & Rubella (1/4096) \\
\hline$-=$ low or negative. & &
\end{tabular}

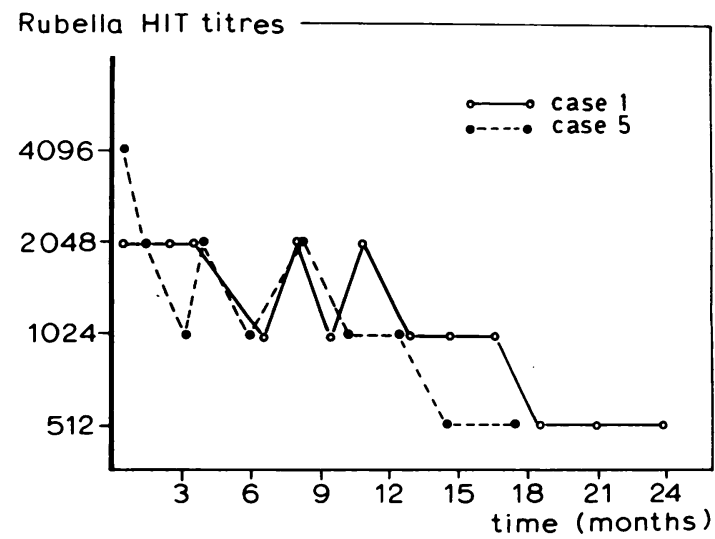

Fig. 1 Course of the rubella haemagglutination inhibition test (HIT) titres in patients 1 and 5. 
rubella $(1 / 2048)$, measles $(1 / 256)$, adenovirus (1/ $128)$, and parainfluenza $1(1 / 1280)$ and $3(1 / 1280)$. This patient also had IgM antibodies to the last two viruses. All other serological tests in these five patients showed low titres or negative results. Table 3 summarises the main virological data for the five patients with adult onset Still's disease.

\section{Discussion}

During the past 15 years several micro-organisms, especially viruses, have been associated with juvenile and adult onset Still's disease. In seroepidemiological studies of patients with juvenile rheumatoid arthritis raised antibody titres to rubella, ${ }^{14}{ }^{15}$ parainfluenza virus, ${ }^{16}$ and Epstein-Barr virus have been found. ${ }^{16}$ The significance of these findings was tempered by the discovery that these antibody increases may reflect a general increase in serum immunoglobulins. ${ }^{1516}$ Another approach, as recently reported by Chantler $e t$ al, has provided much stronger evidence that viruses may play a part in the aetiology of juvenile rheumatoid arthritis. ${ }^{3}$ These investigators were able to isolate rubella from lymphoreticular cells in seven of 19 children with chronic arthritis, including one patient with systemic onset juvenile arthritis (Still's disease), 0.5 to 14 years after onset of the disease. In this study no attempts were made to isolate other virus species. Studies performed during the initial phase in nine cases of juvenile or adult onset Still's disease have led to intriguing observations, suggesting that juvenile or adult onset Still's disease can be triggered by rubella, ${ }^{4-6}$ Coxsackie virus, ${ }^{78}$ adenovirus, ${ }^{7}$ mumps, ${ }^{9}$ Mycoplasma pneumoniae, ${ }^{10}$ and Yersinia enterocolitica. ${ }^{11}$ In addition, one recent prospective study indicates that disease exacerbations in patients with juvenile Still's disease are also closely associated with preceding clinical infections, especially of the upper respiratory tract. ${ }^{12}$ In this last study herpes simplex (one case), rhinovirus (one case), and streptococcus (three cases) were identified as triggering agents.

The present report shows the results of virological studies performed during the initial phase in five consecutive patients with adult onset Still's disease. In one patient (No 3) it appeared very likely that a viral agent had induced the disease. This patient developed clinical and laboratory evidence of adult onset Still's disease at the time of an echovirus 7 infection. Evidence of this infection was acquired by means of virus cultures and serological tests. So far, only one well documented case of acute polyarthritis ascribed to echovirus has been reported in English publications. ${ }^{17}$ This concerns the case of a 35 year old woman with fever, myalgias, and acute poly- arthritis in whom echovirus 9 was isolated from throat and rectal swab specimens. The recognitiors. of echovirus infections is hampered by the fact tha serological evidence of infection with this virus caff be obtained only after virus isolation.

In two patients (Nos 1 and 5) the development oo adult onset Still's disease was probably the result of a rubella infection. Both had initially high Ig® antibody titres but no IgM antibodies to this virus In The Netherlands more than $90 \%$ of young adults (age 18-21 years) possess IgG antibodies to rubella. ${ }^{18}$ Therefore it is much more likely that thes $\overrightarrow{\omega_{0}}$ patients suffered from a reinfection than from so primary infection. Reinfections with rubella gener⿳亠二口欠 ally evoke a rapid IgG but no IgM response. ${ }^{19}$ Fronfe this point of view it is not surprising that the firsto blood specimens in these cases, drawn two weeks after onset of the disease, already showed high titres of $\operatorname{IgG}$ antibodies to rubella but no IgM antibodies음 Polyclonal stimulation in these cases seems unlikely because none had high IgG antibody titres to the other 25 micro-organisms tested. Moreover, none initially showed evidence of hypergammaglobu墕 linaemia. In other rheumatic diseases, such a⿸ rheumatic fever or reactive arthritis, high stable monospecific IgG antibody titres to group A strepo tococci, yersinia, salmonella, campylobacter, ‘opo chlamydia, are generally considered to be of agnostic value. ${ }^{2021}$

Rubella reinfections mostly remain subclinical. ${ }^{2} \frac{2}{0}$ Nevertheless there is circumstantial evidence than arthritis associated with rubella may occur afte reinfections. ${ }^{23-25}$ One report suggests that person $\vec{F}$ suffering from reinfections are even more likely to develop polyarthritis than those with primary infections. ${ }^{25}$ As already mentioned, other investiga? tors have found evidence by virus isolation that rubella infections may induce juvenile or adult onse $\overline{\bar{p}}$ Still's disease..$^{346}$ In the remaining two patient? (Nos 2 and 4) no particular triggering agent could be designated. In one of them high IgG antibody titres to parainfluenza 1 and 3, measles, adenovirus, and rubella and IgM antibodies to parainfluenza were noted, compatible with one or more virus infections or polyclonal stimulation, or both. In the other. patient no raised IgG antibody titres or IgMN antibodies were found.

Most rheumatic diseases are thought to be the result of an interaction between host and environ $\omega$ mental factors. HLA studies in patients with adulp onset Still's disease have shown an increased prevas lence of B14, ${ }^{26} \mathrm{Bw} 35,{ }^{27} \mathrm{Cw} 4,{ }^{27} \mathrm{DR} 4,{ }^{28}$ and DR7. ${ }^{2} \mathrm{C}_{\mathrm{C}}$ The results of the microbiological studies indicate ${ }^{+}$ that in three of our five patients viruses may be añ important exogenous factor in the development of adult onset Still's disease. 
We wish to thank Drs S van Nooten and M Schuurmans for their support in our study of patients Nos 3 and 4, Yvonne Poort for her technical assistance, and Marion Janssen for typing the manuscript.

\section{References}

1 Calabro J J, Holgerson W B, Sonpal G M, Khoury M J. Juvenile rheumatoid arthritis: a general review and report of 100 patients observed for 15 years. Semin Arthritis Rheum 1976; 5: $257-98$.

2 Larson E B. Adult Still's disease: evolution of a clinical syndrome and diagnosis, treatment and follow-up of 17 patients. Medicine (Baltimore) 1984; 63: 82-91.

3 Chantler J K, Tingle A J, Petty R E. Persistent rubella virus infection associated with chronic arthritis in children. $N$ Engl $J$ Med 1985; 313: 1117-23.

4 Harth M, Thompson J M, Ralph E D. Adult-onset Still's disease. Can Med Assoc J 1979; 120: 1507-10.

5 Huang S H K, De Coteau W E. Adult-onset Still's disease: an unusual presentation of rubella infection. Can Med Assoc $J$ 1980; 122: 1275-6.

6 Grahame R, Armstrong R, Simmons N, et al. Chronic arthritis associated with the presence of intrasynovial rubella virus. $A n n$ Rheum Dis 1983; 42: 2-13.

7 Rahal J J, Millian S J, Noriega E R. Coxsackie virus and adenovirus infection. Association with acute febrile juvenile rheumatoid arthritis. JAMA 1976; 235: 2496-501.

8 Heaton D C, Moller P W. Still's disease associated with Coxsackie infection and haemaphagocytic syndrome. Ann Rheum Dis 1985; 44: 341-4.

9 Gordon S C, Lauter C B. Mumps arthritis: unusual presentation as adult Still's disease. Ann Intern Med 1982; 97: 45-7.

10 Dold U, Haelbig Ch. Mycoplasmose und Still syndrom. Munchener Medizinische Wochenschrift 1981; 123: 1908-9.

11 Colebunders R, Stevens W J, Vanagt E, Snoeck J. Adult Still's disease caused by Yersinia enterocolitica infection. Arch Intern Med 1984; 144: 1880-2.

12 De Vere-Tyndall A, Bacon T, Parry R, Tyrrell D A J, Denman A $\mathbf{M}$, Ansell $B$ M. Infection and interferon production in systemic juvenile chronic arthritis: a prospective study. Ann Rheum Dis 1984; 43: 1-7.

13 Medsger T A, Christy W C. Carpal arthritis with ankylosis in late onset Still's disease. Arthritis Rheum 1976; 19: 232-42.

14 Ogra P L, Ogra S S, Chiba Y, Dzierba J L, Herd J K. Rubella- virus infection in juvenile rheumatoid arthritis. Lancet 1975; i: $1157-61$.

15 Linnemann C C, Levinson J E, Buncher C R, Schiff G M. Rubella antibody levels in juvenile rheumatoid arthritis. Ann Rheum Dis 1975; 34: 354-8.

16 Philips P, Lim W, Parkman P, Hirshaut Y. Virus antibody and IgG levels in juvenile rheumatoid arthritis (JRA). Arthritis Rheum 1973; 16: 126.

17 Blotzer J W, Myers A R. Echovirus associated polyarthritis. Arthritis Rheum 1978; 21: 978-81.

18 Conijn-van Spaendonck M A E, Hannik C A, Bijkerk H, et al. Immuunstatus in 1980 van de Nederlandse bevolking vanaf 10 jaar tegen polymyelitis, rubella en morbilli; een serologisch onderzoek. Ned Tijdschr Geneeskd 1984; 128: 1884-7.

19 Balfour Jr H H, Groth K E, Edelman C K. Rubella viraemia and antibody responses after rubella vaccination and reimmunisation. Lancet 1981; i: 1078-80.

20 Barnert A L, Terry E E, Perselin R H. Acute rheumatic fever in adults. JAMA 1975; 232: 925-8.

21 Valtonen V V, Leirisalo M, Pentikäinen P J, et al. Triggering infections in reactive arthritis. Ann Rheum Dis 1985; 44: 399-405.

22 Horstman D M, Liebhaber H, Le Bouvier G L, Rosenberg D A, Halstead S B. Rubella: reinfection of vaccinated and naturally immune persons exposed in an epidemic. $N$ Engl $J$ Med 1970; 283: 771-8.

23 Wilkens J, Leedom J M, Salvatore M A, Portnoy B. Clinical rubella with arthritis resulting from reinfection. Ann Intern Med 1972; 77: 930-2.

24 Tingle A J, Ford D K, Price G E, Kettyls D W G. Prolonged arthritis in identical twins after rubella immunization. Ann Intern Med 1979; 90: 203-4.

25 Chantler J K, Ford D K, Tingle A J. Persistent rubella infections and rubella associated arthritis. Lancet 1982; i: 1323-5.

26 Miller M L, Aaron S, Jackson J, et al. HLA gene frequencies in children and adults with systemic onset juvenile rheumatoid arthritis. Arthritis Rheum 1985; 28: 146-50.

27 Terkeltaub R, Esdaile J, Décary F, et al. HLA Bw35 and prognosis in adult Still's disease. Arthritis Rheum 1981; 24: $1469-72$.

28 Wouters J M G W, Reekers P, van de Putte L B A, Cooperating Centres. Adult-onset Still's disease; disease course and HLA associations. Arthritis Rheum 1986; 29: 415-8. 